\title{
Formation of Dihydroxybenzenes in Cigarette Smoke. Part 2. Contribution from Quinic Acid and Myo-Inositol *
}

\author{
by \\ Serban C. Moldoveanu and Michael F. Davis \\ R. J. Reynolds Tobacco Co., Winston-Salem, NC 27105, USA
}

\section{SUMMARY}

Formation of dihydroxybenzenes in cigarette smoke is a subject of considerable interest because some dihydroxybenzenes are co-carcinogens, (e.g., catechol and certain alkylcatechols), and others such as hydroquinone can form metabolites that have toxic or carcinogenic properties. This present study describes the contribution of tobacco quinic acid (or $(1 S, 3 R, 4 S, 5 R)$-1,3,4,5-tetrahydroxycyclohexanecarboxylic acid) and myo-inositol (or $(1 R, 2 R, 3 S, 4 S, 5 R, 6 S)$-cyclohexane-1,2,3,4,5,6-hexol) to the formation of dihydroxybenzenes in cigarette smoke. The study is a continuation of a previous one showing the contribution of chlorogenic acid and rutin as precursors for these compounds (6). The yields of dihydroxybenzenes formed by pyrolysis of quinic acid and myo-inositol are relatively high and both quinic acid and myo-inositol can be present in some tobacco types at levels as high as $1 \%$ by weight. The level of these compounds makes them potentially important contributors to the formation of dihydroxybenzenes in cigarette smoke. Similar to the previous study on other dihydroxybenzene precursors from tobacco, this present study was done in three parts: 1) pyrolytic evaluation of the amount of dihydroxybenzenes in smoke generated from isolated quinic acid and myoinositol; 2) analysis of smoke from cigarettes made from a variety of tobaccos (14 single grades) and two blended cigarettes, followed by correlations of dihydroxybenzene yields from these cigarettes with the level of quinic acid and myo-inositol in the tobaccos; 3 ) addition of quinic acid or myo-inositol to several tobaccos followed by the smoking of the spiked cigarettes and measurement of the dihydroxybenzenes yield increase. The study performed on a variety of single-grade tobacco cigarettes and for two blended-tobacco cigarettes (one being the 2R4F Kentucky reference) shows that the contribution of quinic acid and of inositol to the formation of catechol and hydroquinone in smoke depends on the blend, as previously shown for chlorogenic acid and rutin. The study results suggest that quinic acid and myo-inositol may be major contributors to the formation of dihydroxybenzenes in cigarette smoke. Although the calculations do not provide precise numbers for the contribution of quinic acid and inositol to the formation of dihydroxybenzenes, these results suggest that the contribution could be as high as 50 to $60 \%$ of the level of dihydroxybenzenes. [Beitr. Tabakforsch. Int. 25 (2013) 535-549]

KEYWORDS: cigarette smoke, catechol, quinic acid, myoinositol

\section{ZUSAMMENFASSUNG}

Die Entstehung von Dihydroxybenzolen im Zigarettenrauch ist von erheblichem Interesse, da einige Dihydroxybenzole Kokarzinogene sind (z. B. Catechol und bestimmte Alkylcatechole) und andere, wie Hydrochinon, Metaboliten mit toxischen oder kanzerogenen Eigenschaften bilden können. In der vorliegenden Studie wird der Beitrag von Chinasäure im Tabak $(1 S, 3 R, 4 S, 5 R)-1,3,4,5$-Tetrahydroxycyclohexancarbonsäure und myo-Inosit $(1 R, 2 R, 3 S, 4 S, 5 R, 6 S)$-Cyclohexan-1,2,3,4,5,6-hexol zur Entstehung von Dihydroxybenzolen im Zigarettenrauch beschrieben. Die Studie ist eine Fortführung einer vorangegangenen Studie, in der der Beitrag von Chlorogensäure und Rutin als Vorläufer dieser Substanzen gezeigt wurde (6). Die Ausbeuten an Dihydroxybenzolen, die 
durch Pyrolyse von Chinasäure und myo-Inosit entstehen, sind relativ hoch, und sowohl Chinasäure als auch myoInosit kann in bestimmten Tabakarten mit bis zu 1\% vorkommen. Aufgrund ihrer Konzentration tragen diese Substanzen potenziell in bedeutsamem Umfang zur Bildung von Dihydroxybenzolen im Zigarettenrauch bei. Ähnlich wie die vorangegangene Studie zu anderen Vorläufern von Dihydroxybenzolen aus Tabak wurde auch diese Studie in drei Teilen durchgeführt: 1) pyrolytische Untersuchung der Menge von Dihydroxybenzolen, die aus den Reinsubstanzen entsteht, 2) Rauchanalyse von Zigaretten aus jeweils einer Tabaksorte (14 einzelne Qualitätsstufen) und zwei Zigaretten aus Tabakmischungen, anschließend Korrelation der Dihydroxybenzol-Ausbeuten aus diesen Zigaretten mit dem Gehalt an Chinasäure und myo-Inosit in den Tabaksorten, 3) Zugabe von Chinasäure oder myo-Inosit zu unterschiedlichen Tabaksorten, anschließend Abrauchen der so präparierten Zigaretten und Messung des Anstiegs der Ausbeute an Dihydroxybenzolen. Die Untersuchung an einer Reihe von Zigaretten aus einer einzigen Tabaksorte und bei zwei Zigaretten aus Tabakmischungen (eine davon die Kentucky-Referenzzigarette 2R4F) ergab, dass der Beitrag von Chinasäure und Inosit zur Entstehung von Catechol und Hydrochinon im Rauch von der Mischung abhängt, wie bereits zuvor für Chlorogensäure und Rutin nachgewiesen wurde. Die Studienergebnisse zeigen, dass Chinasäure und myo-Inosit zur Bildung von Dihydroxybenzolen im Zigarettenrauch wesentlich beitragen können. Auch wenn die Berechnungen keine präzisen Zahlen für den Beitrag von Chinasäure und Inosit zur Entstehung von Dihydroxybenzolen hervorgebracht haben, deuten die Ergebnisse darauf hin, dass dieser sich durchaus auf 50 bis $60 \%$ der Dihydroxybenzolmenge belaufen könnte. [Beitr. Tabakforsch. Int. 25 (2013) 535-549]

\section{RESUME}

La formation de dihydroxybenzènes dans la fumée de cigarette est l'objet d'un grand intérêt en raison du fait que certains dihydroxybenzènes sont co-carcinogènes (par ex. le catéchol ainsi que certains alkylcatéchols), et que d'autres, tels que l'hydroquinone, peuvent former des métabolites ayant des propriétés toxiques ou carcinogènes. La présenté étude décrit la contribution de l'acide quinique présent dans le tabac (ou acide $(1 S, 3 R, 4 S, 5 R)$-1,3,4,5-tétrahydroxycyclohexanecarboxylique) et du myo-inositol (ou (1R,2R,3S,4S,5R,6S)-cyclohexane-1,2,3,4,5,6-hexol) dans la formation de dihydroxybenzènes dans la fumée de cigarette. Cette étude fait suite à une première étude qui a démontré la contribution de l'acide chlorogénique et de la rutine en tant que précurseurs de ces composés (6). Les rendements de dihydroxybenzènes formés par pyrolyse de l'acide quinique et du myo-inositol sont relativement élevés et l'acide quinique de même que le myo-inositol peuvent être présents dans certains types de tabac à des niveaux de concentration pouvant atteindre jusqu'à $1 \%$ en masse. La concentration de ces composants en fait des contributeurs potentiellement importants dans la formation des dihydroxybenzènes dans la fumée de cigarette. De la même manière que dans l'étude précédente portant sur d'autres précurseurs des dihydroxybenzènes, la présente étude a été effectuée en trois parties: 1) l'évaluation pyrolytique de la quantité de dihydroxybenzènes dans la fumée générée à partir d'acide quinique et de myo-inositol isolés; 2) l'analyse de la fumée de cigarettes fabriquées à partir d'une variété de tabacs (14 qualités différentes) et de deux types de cigarettes composées d'un mélange de tabacs, suivie de l'établissement de corrélations entre les teneurs en dihydroxybenzènes de ces cigarettes et la concentration en acide quinique et en myo-inositol dans les tabacs; 3) l'addition d'acide quinique ou de myo-inositol à plusieurs tabacs, suivie par la fume des cigarettes enrichies et la mesure de l'augmentation de la teneur en dihydroxybenzènes. L'étude menée sur une variété de cigarettes composées d'une seule qualité de tabac et sur deux types de cigarettes composées d'un mélange (l'une étant la référence 2R4F Kentucky) montre que la contribution de l'acide quinique et de l'inositol dans la formation du catéchol et de l'hydroquinone dans la fumée dépend du mélange, comme cela a été montré précédemment pour l'acide chlorogénique et la rutine. Les résultats de l'étude suggèrent que l'acide quinique et le myo-inositol sont susceptibles d'être des contributeurs majeurs à la formation des dihydroxybenzènes contenus dans la fumée de cigarette. Bien que les calculs ne fournissent pas de chiffres précis concernant la contribution de l'acide quinique et du $m y o$-inositol dans la formation des dihydroxybenzènes, ces résultats suggèrent que cette contribution pourrait représenter jusqu'à 50 à $60 \%$ de la concentration en dihydroxybenzènes. [Beitr. Tabakforsch. Int. 25 (2013) 535-549]

\section{INTRODUCTION}

A number of studies have been dedicated to the formation of dihydroxybenzenes in cigarette smoke (1-7). The interest in dihydroxybenzenes formation is generated by the fact that some of these compounds act as co-carcinogens (e.g., catechol), or generate toxic/carcinogenic metabolites (8-11). Also, various attempts to reduce the dihydroxybenzenes yield in cigarette smoke have been previously reported in the literature $(2,12)$. However, since several precursors contribute to the formation of dihydroxybenzenes, the elimination or reduction of the level of one or two precursors does not lead to a significant decrease of dihydroxybenzenes from smoke. The detection of as many contributors as possible for the formation of dihydroxybenzenes in smoke is therefore of considerable interest. Based on previously reported pyrolysis products of single compounds (13), quinic acid (or $(1 S, 3 R, 4 S, 5 R)-1,3,4,5$ tetrahydroxycyclohexanecarboxylic acid) and myo-inositol (or $(1 R, 2 R, 3 S, 4 S, 5 R, 6 S)$-cyclohexane-1,2,3,4,5,6-hexol) were identified as being among the potential precursors of dihydroxybenzenes. Following this finding, the levels of quinic acid and myo-inositol were measured in a variety of tobaccos (some commercial blends and some single grades) and correlations with the level of dihydroxybenzenes in smoke were investigated. Further work has been done by adding quinic acid and myo-inositol to two tobaccos followed by smoking of the spiked cigarettes and analysis of dihydroxybenzene formation. The increase in dihydroxybenzenes yield was compared to the initial yield from cigarettes made with the same tobacco but with no 
other compounds added. Conclusions on the contribution of each precursor to hydroquinone and catechol formation have been proposed.

\section{EXPERIMENTAL}

The experiments performed in this study are similar to those previously reported for the evaluation of the contribution of tobacco chlorogenic acid and rutin to smoke dihydroxybenzenes formation (6). It consisted of three different types of experiments. One type was the pyrolysis of pure compounds suspected to be precursors for catechol and other dihydroxybenzenes. The second type was the analysis of quinic acid and myo-inositol in tobaccos, and the third was the analysis of catechol and hydroquinone in smoke from cigarettes made with tobaccos previously analyzed for polyphenols (6). Two of the cigarettes used in this study were commercially available, other cigarettes were made in a pilot plant at R. J. Reynolds Tobacco Co., and other cigarettes were handmade.

\section{Experimental conditions for pyrolysis}

For the pyrolysis of the compounds evaluated in this study, a filament pyrolyzer Pyroprobe 5000 with a 5250-T autosampler (CDS Analytical, CDS, Oxford, PA 19363, USA) on line with a GC/MS instrument was used. The pyrolysis was performed in helium at $900{ }^{\circ} \mathrm{C}$ in flash mode for $20 \mathrm{~s}$. The GC/MS separation and identification of pyrolyzate components was done in conditions previously described in the chlorogenic acid/rutin study (6). Pyrolysis results on isolated compounds do not provide quantitative information on the formation of dihydroxybenzenes in cigarette smoke, but peak areas in pyrograms can be utilized for obtaining estimations regarding the relative yield of a specific compound. The peak area in the pyrograms depends on the amount of the generated compound from a sample and can be used to indicate the expected role of a precursor in the formation of dihydroxybenzenes in smoke.

\section{Experimental conditions for quinic acid and myo-inositol analysis in tobacco}

The analysis of tobacco for quinic acid and myo-inositol was done using a LC/MS/MS method fully described in a previously published paper (14). The separation was achieved using a TSKgel Amide- $804.6 \times 150 \mathrm{~mm}, 3 \mu \mathrm{m}$ column (Tosoh Bioscience LLC, King of Prussia, PA 19406, USA), and detection was done with an API 5000 MS/MS (AB Sciex, Foster City, CA 94404, USA) with multiple reaction monitoring (MRM) mode and negative ionization.

\section{Experimental conditions for the analysis of catechol and hydroquinone in smoke}

The conditions for cigarette smoking and the analysis of catechol and hydroquinone in the collected total particulate matter (TPM) were the same as those described in a previous paper (6). The smoke from the cigarettes was collected with a Cerulean SM 450 smoking machine (Cerulean,
Linford Wood East, MK14 6LY, UK) using a $35 \mathrm{~mL}$ puff volume, $2 \mathrm{~s}$ puff duration, and $60 \mathrm{~s}$ puff interval, with the cigarette filters not having the ventilation blocked (protocol indicated as ISO $(15,16))$. The machine airflows were tuned for ISO conditions $(15,16)$. Smoke from five cigarettes was collected in each run on a 44-mm dia. Cambridge pad. The pads were extracted on a mechanical shaker with $25 \mathrm{~mL}$ water containing $1 \%$ (by volume) acetic acid, $0.1 \%$ (by weight) ascorbic acid, and $4.5 \mu \mathrm{g} / \mathrm{mL}$ vanillic acid (4-hydroxy-3-methoxybenzoic acid), used as an internal standard (all from Aldrich/Sigma, Milwaukee, WI, USA). The extract was analyzed using HPLC following a procedure described in the literature (17).

\section{RESULTS AND DISCUSSION}

\section{Pyrolysis of quinic acid and myo-inositol}

During cigarette smoking, pyrolysis processes play an important role in the formation of smoke components, and numerous attempts have been made to obtain information on smoking from pyrolysis studies $(7,18-21)$. Although cigarette smoke contains most of the pyrolysis products of single compounds present as precursors in tobacco, only rough estimations of the proportion of smoke components can be obtained from pyrolytic studies. The comparison of the peak areas for various molecular species in pyrograms generated from pure compounds offers at best estimations of the yield for many compounds of interest in smoke. However, the nature of components generated from specific precursors can be determined by pyrolysis experiments. The main interest in this present study was related to the formation of dihydroxybenzenes. Because the toxicity of monohydroxybenzenes is typically limited to being corrosive and/or uremic toxins (22), these compounds were not evaluated as part of the present study. The first step was the evaluation of the formation of dihydroxybenzenes by analytical pyrolysis from pure quinic acid and myoinositol. The pyrogram of $1.0 \mathrm{mg}$ quinic acid (performed as indicated in the experimental part) is shown in Figure 1, and that of $1 \mathrm{mg}$ myo-inositol is given in Figure 2.

The identification of each peak resulting from MS spectra is given in Table 1 (see pages 546-548). Individual peak areas normalized by the total areas for both quinic acid and for myo-inositol are also given in Table 1, which shows that a number of hydroxybenzenes are generated in the pyrolyzate. Also shown in Table 1 are the proportions of dihydroxybenzenes formed during quinic acid and myoinositol pyrolysis. These proportions are relatively high making quinic acid and myo-inositol likely precursors for dihydroxybenzenes in cigarette smoke. The formation of dihydroxybenzenes from quinic acid pyrolysis was also previously indicated in the literature $(5,13)$.

Analysis of smoke from cigarettes made from a variety of tobaccos

For further understanding of the contribution of several tobacco constituents to the formation of dihydroxybenzenes, information was necessary about the levels of 


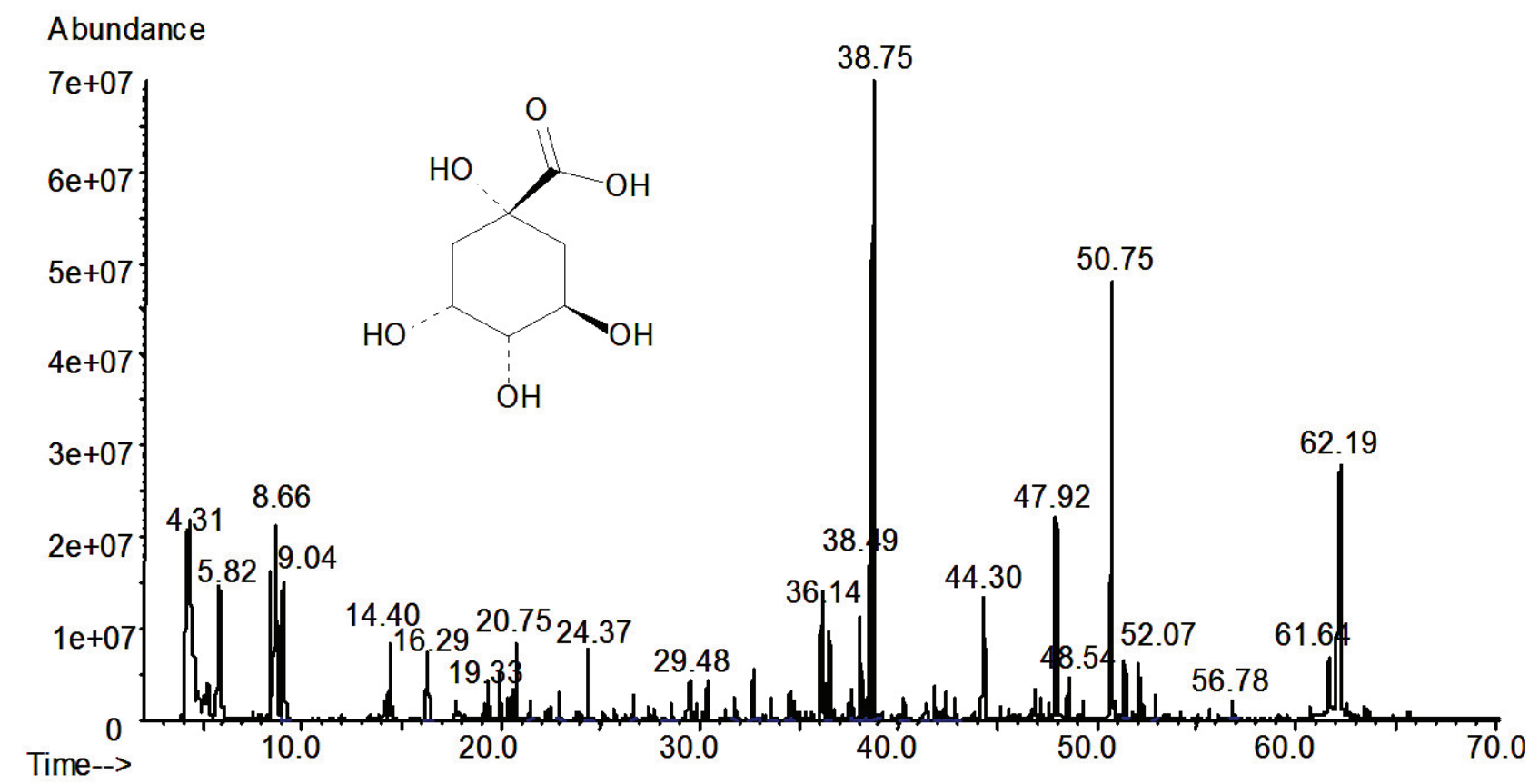

Figure 1. Pyrogram of quinic acid in conditions described in experimental part. Peak identification by MS is given in Table 1 for each specific retention time (in min). Normalized area counts for the peaks are also listed in Table 1.

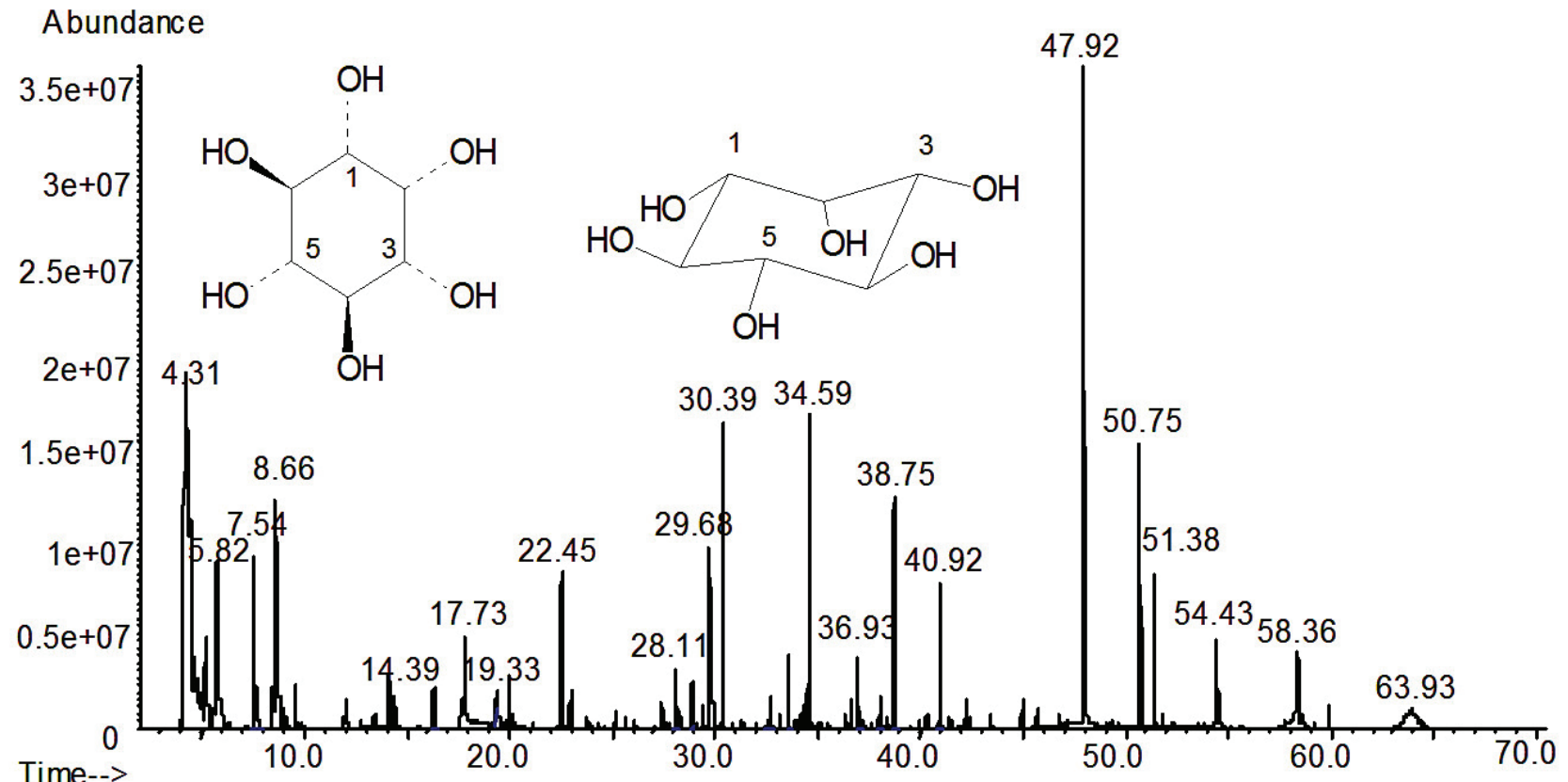

Figure 2. Pyrogram of myo-inositol in conditions described in experimental part. Peak identification by MS is given in Table 1 for each specific retention time (in min). Normalized area counts for the peaks are also listed in Table 1.

quinic acid and myo-inositol in different tobaccos. For this purpose several single-grade tobacco cigarettes, $2 \mathrm{R} 4 \mathrm{~F}$ cigarette, and a commercial cigarette were selected. The single-grade tobacco cigarettes were manufactured at a R. J. Reynolds Tobacco Co. pilot plant to constant tobacco weight. A list of these cigarettes is shown in Table 2 and their main physical characteristics are given in Table 3. The results for quinic acid and myo-inositol levels for these tobaccos were available in the literature (14) and are listed in Table 4. The results for hydroquinone and catechol level in smoke for the cigarettes indicated in Table 2 were also available in the literature (6). 
Table 2. List of single-grade tobacco cigarettes evaluated in the study.

\begin{tabular}{l|l|l}
\hline No & Tobacco identification & Description \\
\hline 1 & L-FC A & Lower stalk (lug) flue-cured A \\
2 & U-FC A & Upper stalk (leaf \& some tips) flue-cured A \\
3 & L-FC B & Lower stalk (lug) flue-cured B \\
4 & U-FC B & Upper stalk (leaf \& some tips) flue-cured B \\
5 & Off L-FC & Off shore, lower stalk (lugs \& primings) flue-cured \\
6 & Off U-FC & Off shore, upper stalk (leaf \& tips) flue-cured \\
7 & L-By A & Lower stalk (flyings \& cutters) Burley A \\
8 & U-By A & Upper stalk (leaf) Burley A \\
9 & L-By B & Lower stalk (flyings \& cutters) Burley B \\
10 & U-By B & Upper stalk (leaf) Burley B \\
11 & Off L-By & Off shore, lower stalk (flyings \& cutters) Burley \\
12 & Off U-By & Off shore, upper stalk (leaf) Burley \\
13 & Or A & Oriental (middle to upper stalk) A \\
14 & Or B & Oriental (middle to upper stalk) B \\
\hline
\end{tabular}

Table 3. The main physical characteristics of single-grade tobacco cigarettes.

\begin{tabular}{lc|r}
\hline Physical property & Units & \multicolumn{1}{l}{ Target } \\
\hline Dilution & $\%$ & 25.0 \\
Draft holes closed & $\mathrm{mm}$ & 155.0 \\
Draft holes open & $\mathrm{mm}$ & 125.0 \\
Cigarette length & $\mathrm{mm}$ & 83.0 \\
Rod length & $\mathrm{mm}$ & 56.0 \\
Filter length & $\mathrm{mm}$ & 27.0 \\
$\begin{array}{l}\text { Circumference } \\
\text { Rod density } \\
\text { (for control only) }\end{array}$ & $\mathrm{mm}$ & 24.48 \\
$\begin{array}{l}\text { Tobacco weight } \\
\text { (for control only) }\end{array}$ & $\mathrm{g} / \mathrm{cc}$ & 0.2478 \\
$\begin{array}{l}\text { Cigarette weight } \\
\text { (for control only) }\end{array}$ & $\mathrm{g}$ & 0.6574 \\
\hline
\end{tabular}

The results for TPM, hydroquinone, catechol as well as for the values of hydroquinone/TPM and catechol/TPM are listed in Table 5. As previously indicated (6), the values for hydroquinone/TPM and catechol/TPM were the highest for the ISO smoking procedure, because the other smoking regimens generate a more diluted TPM material (mainly due to the contribution of water). In this study further comparisons were performed only on TPM generated using ISO smoking conditions.

Figure 3 illustrates the level of hydroquinone/TPM $(\mu \mathrm{g} / \mathrm{mg})$ as a function of quinic acid $(\mathrm{mg} / \mathrm{g}$ tobacco), and Figure 4 illustrates the values of the level of hydroquinone/TPM $(\mu \mathrm{g} / \mathrm{mg})$ as a function of myo-inositol (mg/g tobacco). In both cases, some outlying points shown in the graph were eliminated in order to generate an acceptable positive correlation between the levels of hydro-
Table 4. Results for quinic acid and myo-inositol in the analyzed samples expressed in $\mathrm{mg} / \mathrm{g}$ tobacco (not corrected for moisture)

\begin{tabular}{l|c|c|c}
\hline No. & Sample & $\begin{array}{c}\text { Quinic acid } \\
\mathrm{mg} / \mathrm{g}\end{array}$ & $\begin{array}{c}\text { Myo-inositol } \\
\mathrm{mg} / \mathrm{g}\end{array}$ \\
\hline 1 & L-FC A & 3.99 & 8.14 \\
2 & U-FC A & 4.87 & 5.79 \\
3 & L-FC B & 3.98 & 7.44 \\
4 & U-FC B & 5.66 & 7.86 \\
5 & Off L-FC & 8.97 & 9.23 \\
6 & Off U-FC & 11.45 & 10.18 \\
7 & L-By A & 0.79 & 0.93 \\
8 & U-By A & 1.68 & 1.54 \\
9 & L-By B & 0.92 & 0.77 \\
10 & U-By B & 0.75 & 0.55 \\
11 & Off L-By & 1.93 & 1.11 \\
12 & Off U-By & 2.27 & 1.95 \\
13 & Or A & 4.74 & 4.06 \\
14 & Or B & 6.79 & 15.04 \\
15 & Commercial & 3.84 & 5.95 \\
16 & 2R4F & 3.49 & 5.25 \\
\hline
\end{tabular}

quinone/TPM and the level of quinic acid or myo-inositol (the selection of outlier points has been done visually). After these points were eliminated, a value of $\mathrm{R}^{2}=0.8153$ was obtained for the correlation hydroquinone/TPM vs. quinic acid, and a value of $\mathrm{R}^{2}=0.8249$ was obtained for the correlation hydroquinone/TPM vs. myo-inositol. These relatively high values for $\mathrm{R}^{2}$ indicate the possibility that some of the hydroquinone in cigarette smoke is generated from quinic acid and from myo-inositol. The outliers were possibly caused by the presence of other major precursors for hydroquinone, such as chlorogenic acid, rutin, or carbohydrates. 
Table 5. Levels of TPM in $\mathrm{mg} / \mathrm{cig}$ and of hydroquinone and catechol in $\mu \mathrm{g} / \mathrm{cig}$.

\begin{tabular}{l|c|c|c|c|c|c}
\hline No & $\begin{array}{c}\text { Tobacco } \\
\text { identification }\end{array}$ & TPM mg/cig & $\begin{array}{c}\text { Hydroquinone } \\
\mu \mathrm{g} / \mathrm{cig}\end{array}$ & $\begin{array}{c}\text { Catechol } \\
\mu \mathrm{g} / \mathrm{cig}\end{array}$ & $\begin{array}{c}\text { Hydroqinone/TPM } \\
\mu \mathrm{g} / \mathrm{mg}\end{array}$ & $\begin{array}{c}\text { Catechol/TPM } \\
\mu \mathrm{g} / \mathrm{mg}\end{array}$ \\
\hline 1 & L-FC A & 13.50 & 29.01 & 40.61 & 2.149 & 3.008 \\
2 & U-FC A & 15.88 & 54.42 & 49.18 & 3.427 & 3.097 \\
3 & L-FC B & 10.81 & 22.76 & 24.4 & 2.105 & 2.257 \\
4 & U-FC B & 16.62 & 68.83 & 62.34 & 4.141 & 3.751 \\
5 & Off L-FC & 11.44 & 55.97 & 51.61 & 4.892 & 4.511 \\
6 & Off U-FC & 14.91 & 71.13 & 74.71 & 4.771 & 5.011 \\
7 & L-By A & 11.93 & 0.00 & 7.70 & 0.000 & 0.645 \\
8 & U-By A & 14.15 & 10.37 & 16.44 & 0.733 & 1.162 \\
9 & L-By B & 12.36 & 7.33 & 12.19 & 0.593 & 0.986 \\
10 & U-By B & 13.27 & 3.78 & 12.44 & 0.285 & 0.937 \\
11 & Off L-By & 9.09 & 76.83 & 20.96 & 8.452 & 2.306 \\
12 & Off U-By & 9.13 & 75.35 & 28.35 & 8.253 & 3.105 \\
13 & Or A & 13.97 & 24.74 & 44.47 & 1.771 & 3.183 \\
14 & Or B & 14.53 & 39.39 & 65.87 & 2.711 & 4.533 \\
15 & Commercial & 12.40 & 34.77 & 35.39 & 2.804 & 2.854 \\
16 & 2R4F & 11.46 & 29.30 & 37.90 & 2.557 & 3.307 \\
\hline
\end{tabular}

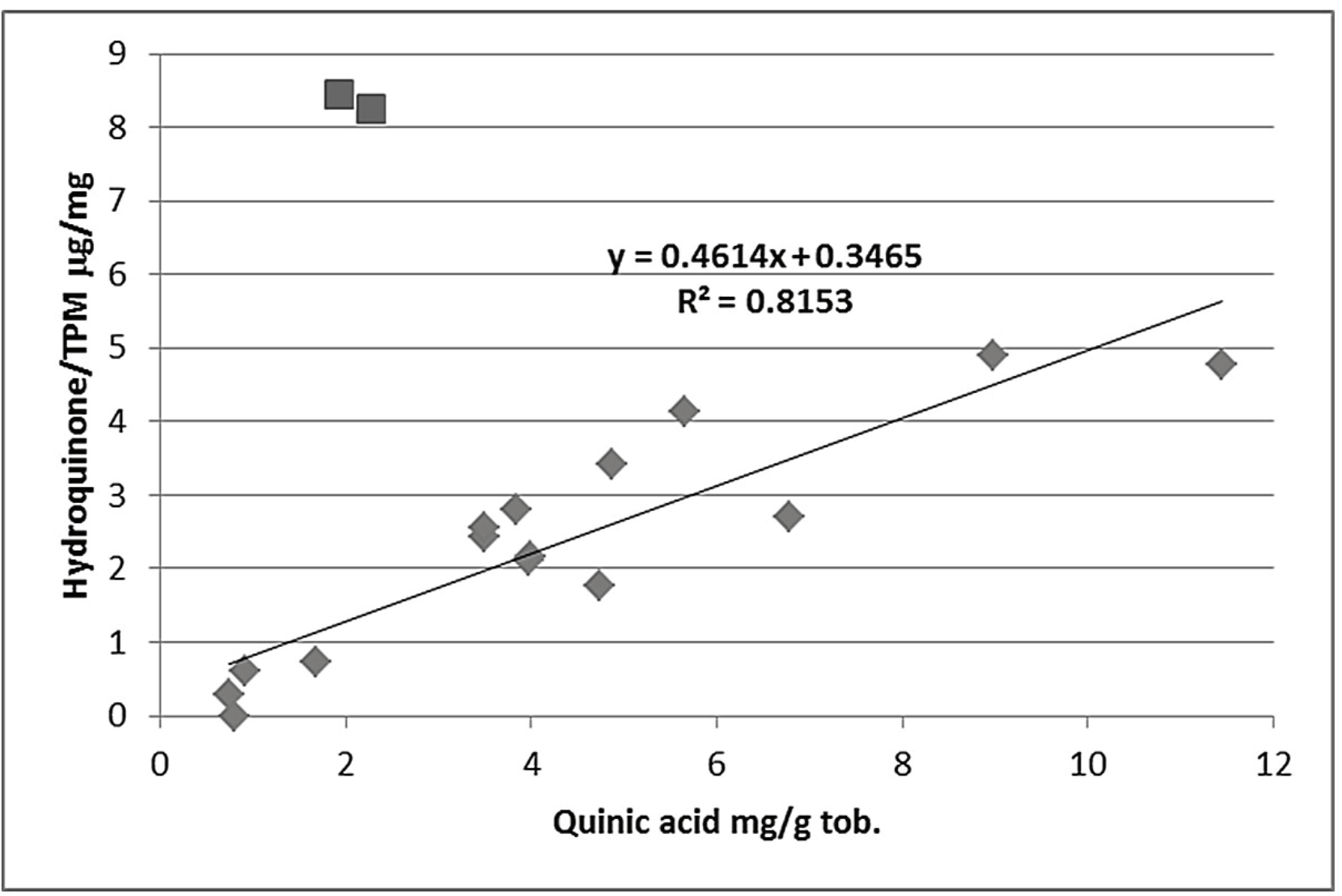

Figure 3. Plot representing the values of the level of hydroquinone/TPM $(\mu \mathrm{g} / \mathrm{mg})$ as a function of quinic acid ( $\mathrm{mg} / \mathrm{g}$ tobacco) (two outlier points not included in the correlation).

The correlations for catechol similar to those indicated for hydroquinone are shown in Figures 5 and 6, respectively. Figure 5 shows the plot of the levels of catechol/TPM $(\mu \mathrm{g} / \mathrm{mg})$ as a function of quinic acid level (mg/g tobacco) with $\mathrm{R}^{2}=0.7979$ for the correlation, and Figure 6 shows the plot of the levels of catechol/TPM $(\mu \mathrm{g} / \mathrm{mg})$ as a function of $m y o$-inositol level ( $\mathrm{mg} / \mathrm{g}$ tobacco) with $\mathrm{R}^{2}=0.6826$ for the correlation. In the case of catechol, no outliers were 


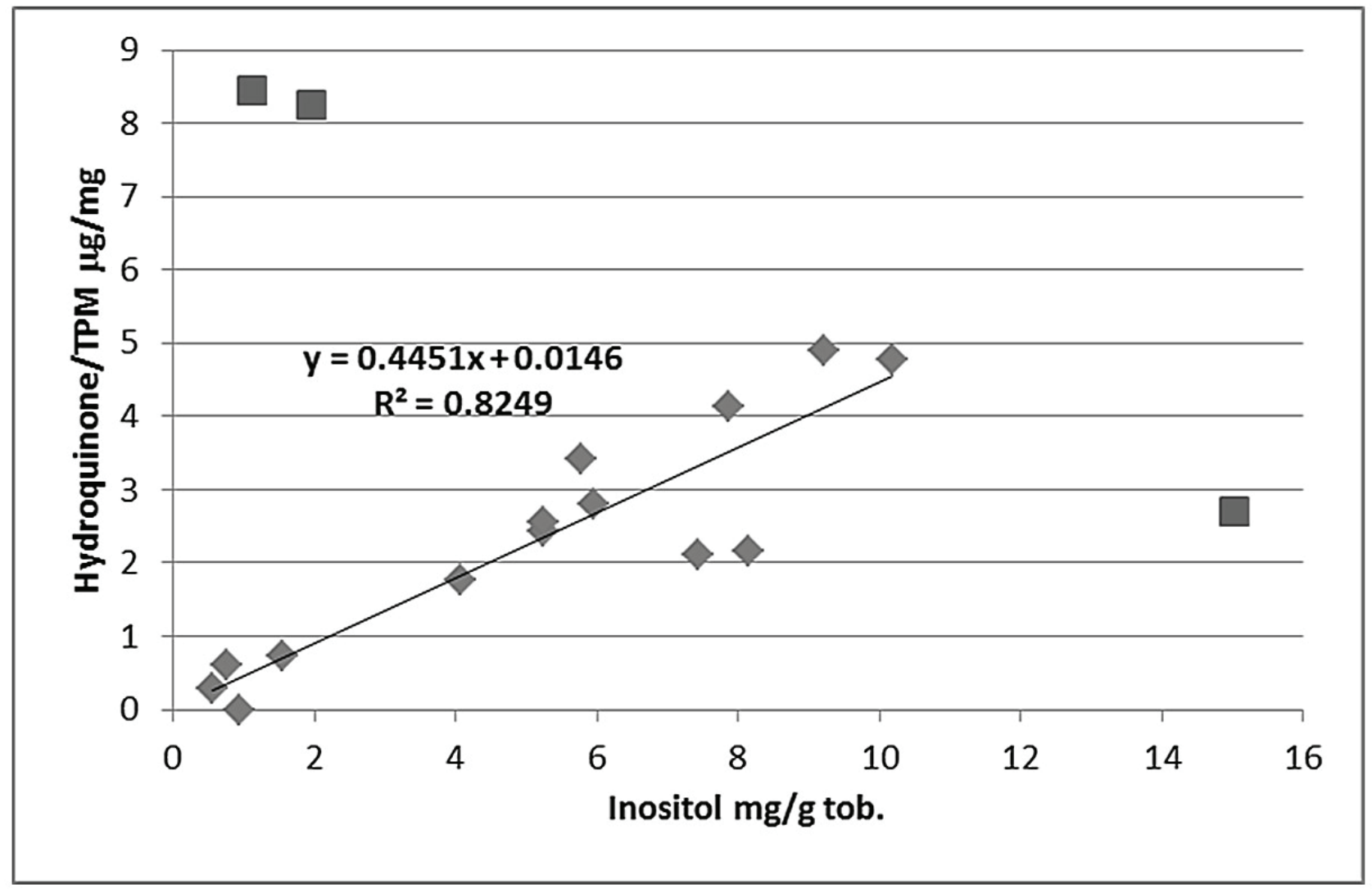

Figure 4. Plot representing the values of the level of hydroquinone/TPM $(\mu \mathrm{g} / \mathrm{mg})$ as a function of $m y o$-inositol ( $\mathrm{mg} / \mathrm{g}$ tobacco) (three outlier points not included in the correlation).

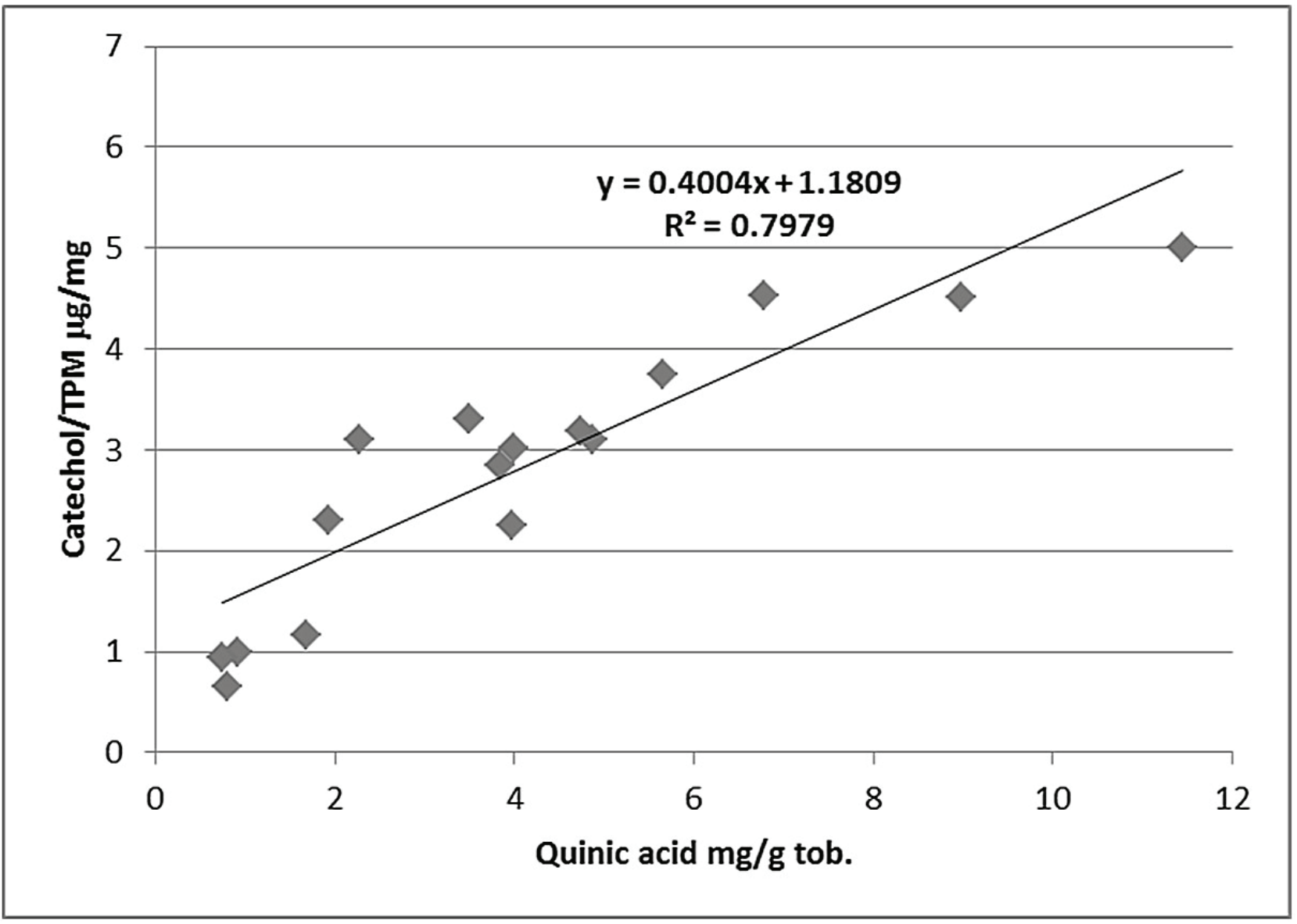

Figure 5. Plot representing the values of the level of catechol/TPM $(\mu \mathrm{g} / \mathrm{mg})$ as a function of quinic acid (mg/g tobacco). 


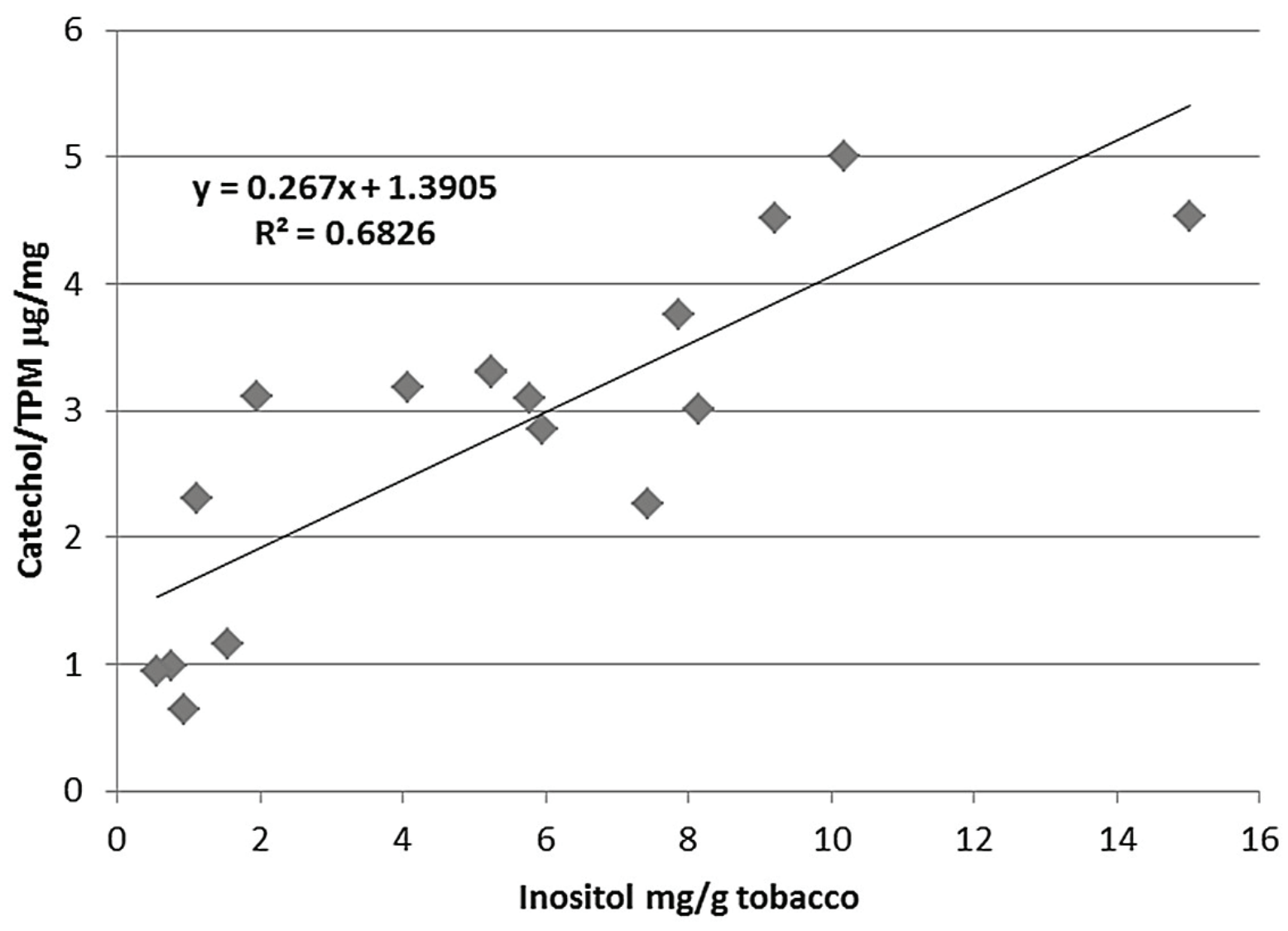

Figure 6. Plot representing the values of the level of catechol/TPM $(\mu \mathrm{g} / \mathrm{mg})$ as a function of $m y o-i n o s i t o l ~(m g / g ~ t o b a c c o)$.

noticed. Even better correlation is obtained for the dependence of catechol/TPM versus the sum (quinic acid + myoinositol), with $\mathrm{R}^{2}=0.8018$. The graph showing this dependence is given in Figure 7 . The relatively good positive correlation shown in Figures 3 to 7 indicates that quinic acid and myo-inositol are potential precursors for catechol in cigarette smoke. Because both catechol and hydroquinone are seen in pyrolysis products of quinic acid and of myo-inositol, the correlations strongly indicate relationship.

Addition of quinic acid and myo-inositol to several tobaccos

Further work was conducted for the evaluation of the contribution to the formation of catechol and hydroquinone in smoke from tobacco quinic acid and myo-inositol. This was done by adding exogenous quinic acid and myo-inositol to a Burley tobacco and to 2R4F tobacco, followed by making handmade cigarettes that were smoked and then the TPM analyzed for catechol and hydroquinone by HPLC. For each treatment about $15 \mathrm{~g}$ of tobacco was removed from the cigarettes. One portion of tobacco was treated in a plastic bag with $15 \mathrm{~mL}$ water. The cigarettes made from this tobacco were used as the control for the cigarettes with added quinic acid or myo-inositol. Another portion of about $15 \mathrm{~g}$ tobacco was treated with a $15 \mathrm{~mL}$ solution containing $10 \mathrm{mg} / \mathrm{mL}$ of quinic acid or myo- inositol, respectively. Each tobacco sample was soaked in the solution for $30 \mathrm{~min}$, dried at $75^{\circ} \mathrm{C}$ in an oven for about $30 \mathrm{~min}$, and then kept in a conditioning chamber at $18.5^{\circ} \mathrm{C}$ and $65 \%$ relative humidity for 48 hours. The tobacco was then handmade into cigarettes (using the initial spills). Each cigarette was made with $0.655 \mathrm{~g} \pm 10 \mathrm{mg}$ of tobacco. The cigarettes were conditioned and smoked as indicated in the experimental section. Part of the remaining tobacco was analyzed for quinic acid and myo-inositol content. The results regarding the analyzed levels of quinic acid and myo-inositol in each tobacco sample are given in Table 6. Each analysis was performed in duplicate. The RSD\% levels were approximately $4.0 \%$ for samples with additional quinic acid and $4.3 \%$ for samples with added myoinositol. As seen in Table 6 , the target of added $10 \mathrm{mg} / \mathrm{g}$ for either quinic acid or myo-inositol was not perfectly achieved. This is because part of the added solution remained on the walls of the plastic bag where the treatment was done and did not stay only on the tobacco. Therefore, lower levels than the target were not unexpected. A higher level of quinic acid in one of the samples may have been caused by the variability of the added level of quinic acid in the leaf or to the variability in the analysis.

The results regarding the yields of TPM, catechol, and hydroquinone obtained for each cigarette are given in Table 7. Each analysis was performed in triplicate (of cigarettes) and the resulting RSD\% values were less than 7\% for hydroquinone measurements and less than $6 \%$ for 


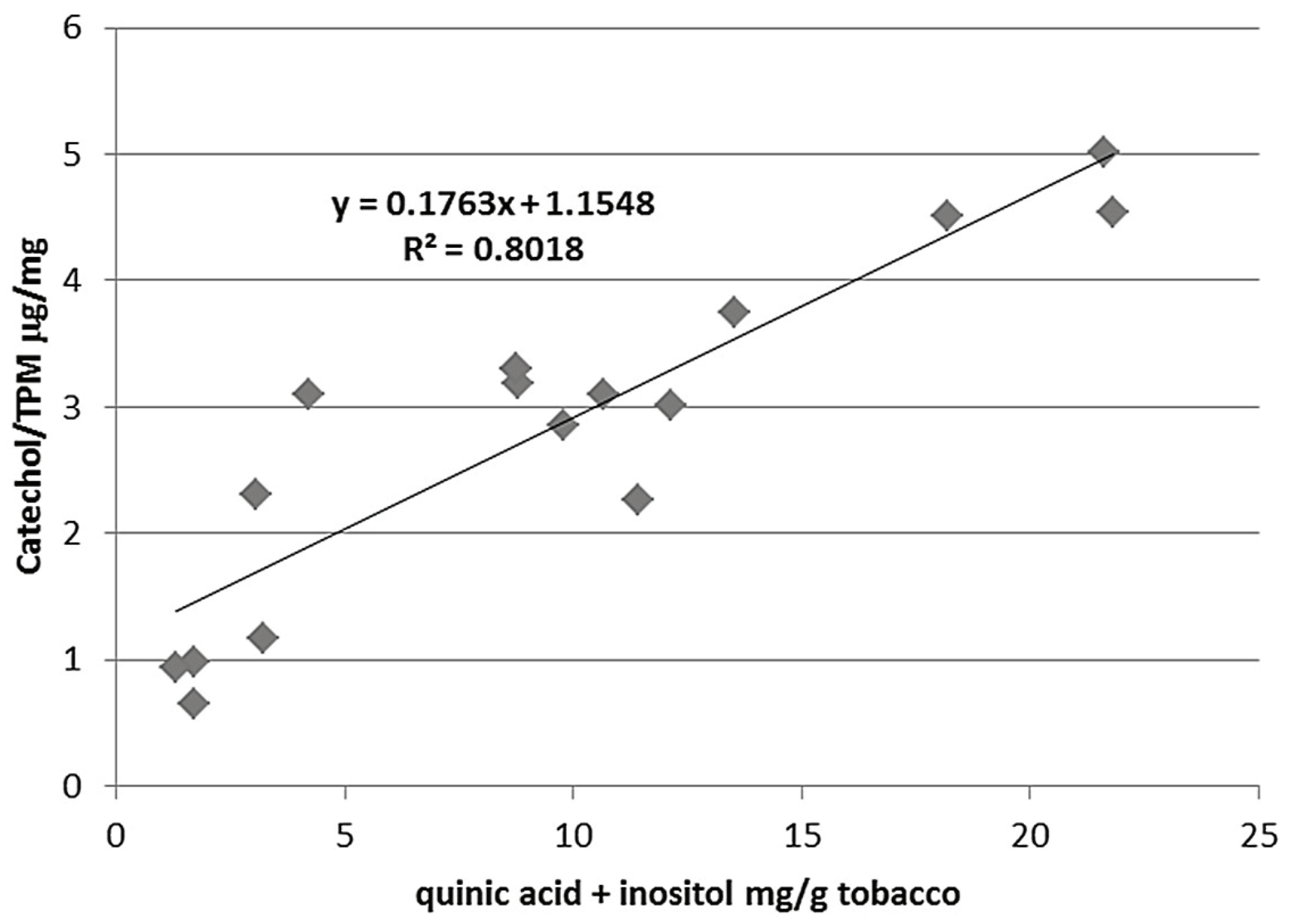

Figure 7. Plot representing the values of the level of catechol/TPM $(\mu \mathrm{g} / \mathrm{mg})$ as a function of the sum of quinic acid $+m y o-i n o s i t o l$ (mg/g tobacco).

Table 6. Levels of quinic acid and myo-inositol in tobacco samples with added $10 \mathrm{mg}$ of quinic acid or 10 mg myo-inositol (inos.).

\begin{tabular}{|c|c|c|c|c|c|c|c|}
\hline No & Tobacco identification & $\begin{array}{l}\text { Added quinic } \\
\text { acid } \mathrm{mg} / \mathrm{g}\end{array}$ & $\begin{array}{c}\text { Measured quinic } \\
\text { acid } \mathrm{mg} / \mathrm{g}\end{array}$ & $\begin{array}{l}\text { Difference in } \\
\text { quinic acid }\end{array}$ & $\begin{array}{l}\text { Added } \mathrm{myo}- \\
\text { inositol } \mathrm{mg} / \mathrm{g}\end{array}$ & $\begin{array}{c}\text { Measured inositol } \\
\mathrm{mg} / \mathrm{g}\end{array}$ & $\begin{array}{c}\text { Difference in } \\
\text { myo-inositol mg/g }\end{array}$ \\
\hline 7 & L-By A control & 0 & 0.68 & - & 0 & 0.89 & - \\
\hline $7 a$ & L-By $A+10$ quinic & 10 & 10.89 & 10.21 & 0 & - & - \\
\hline $7 b$ & L-By A + 10 inos. & 0 & - & - & 10 & 9.81 & 8.92 \\
\hline $2 \mathrm{R} 4 \mathrm{~F}$ & 2R4F control & 0 & 3.22 & - & 0 & 5.11 & \\
\hline $2 \mathrm{R} 4 \mathrm{Fa}$ & $2 \mathrm{R} 4 \mathrm{~F}+10$ quinic & 5 & 12.23 & 9.01 & 0 & - & - \\
\hline $2 \mathrm{R} 4 \mathrm{Fb}$ & $2 \mathrm{R} 4 \mathrm{~F}+10$ inos. & 0 & - & - & 10 & 12.76 & 7.65 \\
\hline
\end{tabular}

Note: The tobacco controls L-By A, and 2R4F in Table 6 were treated with water and processed similarly as tobacco spiked with quinic acid and myo-inositol.

catechol measurements. The data from Tables 6 and 7 were further used for the calculation of the increase in hydroquinone and catechol yields upon the addition of quinic acid and myo-inositol to the tobacco. The results for spiked cigarettes are shown in Table 8, together with the calculation of an "average" contribution to the formation of hydroquinone and of catechol from the addition of $1 \mathrm{mg}$ of each of the two compounds. Based on these calculated values, and using the measured levels of quinic acid and of myo-inositol in tobacco, it was possible to estimate the contribution of these two precursors to the formation of hydroquinone and catechol in the smoke of the sample cigarettes. The results are given in Table 9. The results from Table 9 indicate that a considerable proportion of the hydroquinone and catechol in cigarette smoke can be attributed to quinic acid and myo-inositol as precursors. The accuracy of the results is difficult to estimate. The calculations prove that quinic acid and myo-inositol are very likely important contributors to the formation of hydroquinone and catechol in cigarette smoke with possible yields as high as $70-80 \%$. Also, the calculations show that the contribution of these precursors to the formation of hydroquinone and catechol, strongly depend on the blend composition. Previously published results (6) show that 
Table 7. Levels of TPM, hydroquinone and catechol for cigarettes made with tobacco spiked with 10 mg of quinic acid or myoinositol.

\begin{tabular}{l|c|c|c|c|c|c}
\hline No & Tobacco identification & $\begin{array}{c}\text { TPM } \\
\mathrm{mg} / \mathrm{cig}\end{array}$ & $\begin{array}{c}\text { Hydroqinone } \\
\mu \mathrm{g} / \mathrm{cig}\end{array}$ & $\begin{array}{c}\text { Catechol } \\
\mu \mathrm{g} / \mathrm{cig}\end{array}$ & $\begin{array}{c}\text { Hydroquinone/ } \\
\text { TPM } \mu \mathrm{g} / \mathrm{mg}\end{array}$ & $\begin{array}{c}\text { Catechol/TPM } \\
\mu \mathrm{g} / \mathrm{mg}\end{array}$ \\
\hline 7 & L-By A control & 10.20 & 1.45 & 4.4 & 0.142 & 0.431 \\
7a & L-By A + 10 quinic acid & 10.49 & 22.9 & 35.2 & 2.183 & 3.356 \\
7b & L-By A + 10 myo-inos. & 10.57 & 15.2 & 22.0 & 1.438 & 2.082 \\
2R4F & 2R4F control & 10.88 & 20.3 & 26.3 & 1.866 & 2.418 \\
2R4Fa & 2R4F + 10 quinic acid & 7.78 & 26.2 & 33.1 & 3.369 & 4.256 \\
2R4Fb & 2R4F + 10 myo-inos. & 8.33 & 23.3 & 31.4 & 2.796 & 3.768 \\
\hline
\end{tabular}

Note: The controls L-By A, and 2R4F in Table 7 are handmade cigarettes using tobacco treated with water and the levels of TPM, hydroquinone and catechol are not identical with those from Table 5.

Table 8. Differences versus control in the levels of hydroquinone/TPM and catechol/TPM for the spiked samples, and the values normalized by the correct amount of quinic acid and myo-inositol added.

\begin{tabular}{l|c|c|c|c|c}
\hline No & $\begin{array}{c}\text { Sample } \\
\text { identification }\end{array}$ & $\begin{array}{c}\text { Hydroquinone/TPM } \\
\text { Diff. to control } \\
\mu \mathrm{g} / \mathrm{mg}\end{array}$ & $\begin{array}{c}\text { Catechol/TPM } \\
\text { Diff. to control } \mu \mathrm{g} / \mathrm{mg}\end{array}$ & $\begin{array}{c}\text { Hydroquinone/TPM } \\
\mu \mathrm{g} / \mathrm{mg} \text { for } \\
1 \mathrm{mg} \text { added }\end{array}$ & $\begin{array}{c}\text { Catechol/TPM } \\
\mu \mathrm{m} / \mathrm{mg} \text { for } \\
1 \mathrm{mg} \text { added }\end{array}$ \\
\hline 7a & L-By A + 10 quinic acid & 2.041 & 2.925 & 0.200 & 0.286 \\
$7 \mathrm{~b}$ & L-By A + 10 myo-inositol & 1.296 & 1.651 & 0.145 & 0.185 \\
2R4Fa & 2R4F + 10 quinic acid & 1.502 & 1.838 & 0.167 & 0.204 \\
2R4Fb & 2R4F + 10 myo-inositol & 0.930 & 1.350 & 0.122 & 0.177 \\
Average after 1mg quinic acid addition & & & 0.183 & 0.245 \\
Average after 1 mg myo-inositol addition & & & 0.133 & 0.181 \\
\hline
\end{tabular}

Table 9. Hypothetical calculation of formation of hydroquinone and catechol from quinic acid and from myo-inositol in cigarette smoke.

\begin{tabular}{|c|c|c|c|c|c|c|c|c|c|}
\hline \multirow{2}{*}{ No } & \multirow{2}{*}{$\begin{array}{c}\text { Tobacco } \\
\text { identification }\end{array}$} & \multicolumn{2}{|c|}{$\begin{array}{l}\text { Hydroquinone/TPM } \\
\mu \mathrm{g} / \mathrm{mg}\end{array}$} & \multicolumn{2}{|c|}{$\begin{array}{c}\text { Catechol/TPM } \\
\mu \mathrm{g} / \mathrm{mg}\end{array}$} & \multirow{2}{*}{$\begin{array}{c}\begin{array}{c}\text { Hydroq./ } \\
\text { TPM } \\
\mu \mathrm{g} / \mathrm{mg}\end{array} \\
\text { Total }\end{array}$} & \multirow{2}{*}{\begin{tabular}{|c|}
$\begin{array}{c}\text { Catechol/ } \\
\text { TPM } \\
\mu \mathrm{g} / \mathrm{mg}\end{array}$ \\
Total
\end{tabular}} & \multirow{2}{*}{\begin{tabular}{|c|}
$\begin{array}{c}\text { Hydroq./ } \\
\text { TPM } \\
\mu \mathrm{g} / \mathrm{mg}\end{array}$ \\
$\begin{array}{c}\% \text { from } \\
\text { measured }\end{array}$ \\
\end{tabular}} & \multirow{2}{*}{$\begin{array}{c}\begin{array}{c}\text { Catechol/ } \\
\text { TPM } \\
\mu \mathrm{g} / \mathrm{mg}\end{array} \\
\begin{array}{c}\text { from } \\
\text { measurec }\end{array} \\
\end{array}$} \\
\hline & & From quinic acid & $\begin{array}{c}\text { From } \\
\text { myo-inositol }\end{array}$ & $\begin{array}{l}\text { From quinic } \\
\text { acid }\end{array}$ & $\begin{array}{c}\text { From } \\
\text { myo-inositol }\end{array}$ & & & & \\
\hline 1 & L-FC A & 0.731 & 1.086 & 0.978 & 1.472 & 1.818 & 2.450 & 84.6 & 81.4 \\
\hline 2 & U-FC A & 0.893 & 0.773 & 1.194 & 1.047 & 1.665 & 2.241 & 48.6 & 72.4 \\
\hline 3 & L-FC B & 0.730 & 0.993 & 0.976 & 1.345 & 1.722 & 2.321 & 81.8 & 102.8 \\
\hline 4 & U-FC B & 1.038 & 1.049 & 1.388 & 1.421 & 2.086 & 2.809 & 50.4 & 74.9 \\
\hline 5 & Off L-FC & 1.644 & 1.232 & 2.200 & 1.669 & 2.876 & 3.868 & 58.8 & 85.7 \\
\hline 6 & Off U-FC & 2.099 & 1.358 & 2.808 & 1.840 & 3.457 & 4.648 & 72.5 & 92.8 \\
\hline 7 & L-By A & 0.145 & 0.124 & 0.194 & 0.168 & 0.269 & 0.362 & - & 56.1 \\
\hline 8 & U-By A & 0.308 & 0.205 & 0.412 & 0.278 & 0.513 & 0.690 & 70.1 & 59.4 \\
\hline 9 & L-By B & 0.169 & 0.103 & 0.226 & 0.139 & 0.271 & 0.365 & 45.8 & 37.0 \\
\hline 10 & U-By B & 0.137 & 0.073 & 0.184 & 0.099 & 0.211 & 0.283 & 74.0 & 30.2 \\
\hline 11 & Off L-By & 0.354 & 0.148 & 0.473 & 0.201 & 0.502 & 0.674 & 5.9 & 29.2 \\
\hline 12 & Off U-By & 0.416 & 0.260 & 0.557 & 0.353 & 0.676 & 0.909 & 8.2 & 29.3 \\
\hline 13 & Or A & 0.869 & 0.542 & 1.162 & 0.734 & 1.411 & 1.896 & 79.7 & 59.6 \\
\hline 14 & Or B & 1.245 & 2.007 & 1.665 & 2.719 & 3.252 & 4.384 & 119.9 & 96.7 \\
\hline 15 & Commercial & 0.704 & 0.794 & 0.942 & 1.076 & 1.498 & 2.017 & 53.4 & 70.7 \\
\hline 16 & $2 \mathrm{R} 4 \mathrm{~F}$ & 0.640 & 0.701 & 0.856 & 0.949 & 1.340 & 1.805 & 52.4 & 54.6 \\
\hline
\end{tabular}

chlorogenic acid and rutin, which were suspected for a long time to be the main precursors of hydroquinone and catechol in cigarette smoke, are only modest contributors.
This present study suggests that quinic acid and myo-inositol from tobacco are potentially major contributors to dihydroxybenzenes formation during smoking. 


\section{CONCLUSIONS}

The present study evaluated the contribution of quinic acid and myo-inositol to the formation of hydroquinone and catechol in cigarette smoke. The results show that for a variety of single-grade tobacco cigarettes and for two blended cigarettes (one being 2R4F Kentucky reference), the contribution of quinic acid and myo-inositol to the formation of catechol and hydroquinone is dependent on the blend. Also, the study suggests that quinic acid and myoinositol may be major contributors to the formation of dihydroxybenzenes in cigarette smoke. Although the calculations from this study provide only estimates for the contribution of quinic acid and myo-inositol to the formation of dihydroxybenzenes, this contribution is shown to be high. For samples 7 (L-By_A) and 16 (2R4F) the contribution is probably close to 50 to $60 \%$, while for other tobaccos the contribution can be lower or higher than this level, and is very likely significant.

\section{ACKNOWLEDGEMENT}

The authors wish to express their thanks to Dr Hubert Klus for pointing out that the generation of catechol in cigarette smoke from quinic acid in tobacco was previously predicted by E. MOLINARI (23).

\section{REFERENCES}

1. Carmella, S.G., S.S. Hecht, T.C. Tso, and D. Hoffmann: Roles of tobacco cellulose, sugars and chlorogenic acid as precursors to catechol in cigarette smoke; J. Agric. Food Chem. 32 (1984) 267-273.

2. Schlotzhauer, W.S., M.E. Snook, O.T. Chortyk, and R.L. Wilson: Pyrolytic evaluation of low chlorogenic acid tobaccos in the formation of the tobacco smoke co-carcinogen catechol; J. Anal. Appl. Pyrol. 22 (1992) 231-238.

3. Schlotzhauer, W.S. and O.T. Chortyk: Pyrolytic studies on the origin of phenolic compounds in tobacco smoke; Tob. Sci. 25 (1981) 6-10.

4. McGrath, T.E., A.P. Brown, N.K. Meruva, and W.G. Chan: Phenolic compound formation from the low temperature pyrolysis of tobacco; J. Anal. Appl. Pyrol. 84 (2009) 170-178.

5. Dyakonov, A.J., R.T. Walker, C.A. Brown, F.R. Perini, D.S. Passer, J. Guan, and E.A. Robinson: Studies of the Formation of Smoke Phenols; Beitr. Tabakforsch. Int. 23 (2008) 68-84.

6. Davis, M.F., H.D. Mills, and S.C. Moldoveanu: Formation of Dihydroxybenzenes in Cigarette Smoke. Part 1. Contribution from Chlorogenic Acid and Rutin; Beitr. Tabakforsch. Int. 25 (2012) 396-408.

7. Baker, R.R. and L.J. Bishop: The pyrolysis of tobacco ingredients; J. Anal. Appl. Pyrol. 71 (2004) 223-311.

8. Chouchane, S., J.B. Wooten, F.J. Tewes, A. Wittig, B.P. Müller, D. Veltel, and J. Diekmann: Involvement of semiquinone radicals in the in vitro cytotoxicity of cigarette mainstream smoke; Chem. Res. Toxicol. 19 (2006) 1602-1610.
9. Gopalakrishna, R., Z.-H. Chen, and U. Gundimeda: Tobacco smoke tumor promoters, catechol and hydroquinone, induce oxidative regulation of protein kinase $\mathrm{C}$ and influence invasion and metastasis of lung carcinoma cells; Proc. Natl. Acad. Sci. 91 (1994) 12233-12237.

10. Lau, S.S., T.J. Monks, J.I. Everitt, E. Kleymenova, and C.L. Walker: Carcinogenicity of a nephrotoxic metabolite of the "nongenotoxic" carcinogen hydroquinone; Chem. Res. Toxicol. 14 (2001) 25-33.

11. Swirsky Gold, L. (Ed.): The carcinogenic potency database (CPDB); available at http://potency. berkeley.edu/ (accessed March 2013)

12. Liu, C., Y. DeGrandpré, A. Porter, A. Griffiths, K. McAdam, R. Voisine, F. Côté, and C. Proctor: The use of a novel tobacco treatment process to reduce toxicant yields in cigarette smoke; Food Chem. Toxicol. 49 (2011) 1904-1917.

13. Moldoveanu, S.C.: Pyrolysis of organic molecules with applications to health and environmental issues; Elsevier, Amsterdam, The Netherlands, 2010, pp. 291-293 and 498-503.

14. Moldoveanu, S.C. and M.F. Davis: Analysis of Quinic Acid and of myo-Inositol in Tobacco; Beitr. Tabakforsch. Int. 25 (2012) 498-506.

15. International Organisation for Standardisation (ISO): International Standard ISO 3308:1991 (E). Routine analytical cigarette smoking machine - definitions and standard conditions. ISO, Geneva, Switzerland, 1991.

16. International Organisation for Standardisation (ISO): International Standard ISO 4387:1991 (E) Cigarette Determination of total and nicotine free dry particulate matter using a routine analytical smoking machine. ISO, Geneva, Switzerland, 1991.

17. Moldoveanu, S.C. and M. Kiser: Gas chromatography/mass spectrometry versus liquid chromatography/ fluorescence detection in the analysis of phenols in mainstream cigarette smoke; J. Chromatogr. A 1141 (2007) 90-97.

18. Moldoveanu, S.C.: Analytical pyrolysis of natural organic polymers; Elsevier, Amsterdam, 1998, pp. 53-54.

19. Jenkins Jr., R.W., R.H. Newman, and M.K. Chavis: Cigarette Smoke Formation Studies. II. Smoke Distribution and Mainstream Pyrolytic Composition of Added ${ }^{14} \mathrm{C}$-menthol (U); Beitr. Tabakforsch. 5 (1970) 299-301.

20. Moldoveanu, S.C.: Pyrolysis of organic molecules with applications to health and environmental issues; Elsevier, Amsterdam, 2010 pp. 298-305.

21. Stotesbury, S.J., H. Digard, L.J. Willoughby, and A. Couch: The Pyrolysis of Tobacco Additives As A Means of Predicting Their Behavior in A Burning Cigarette; Beitr. Tabakforsch. Int. 18 (1999) 147-163.

22. De Smet, R., J. Van Kaer, B. Van Vlem, A. De Cubber, P. Brunet, N. Lamaire, and R. Vanholder: Toxicity of free $p$-cresol: A prospective and cross-sectional analysis; Clin. Chem. 49 (2003) 470-478.

23. Molinari, E.: The occurrence of phenols in tobacco smoke [Über das Auftreten von Phenolen im Tabakrauch]; Fachl. Mitt. Österr. Tabakregie 3 (1936) 14-16. 
Table 1. Identification of the main peaks in the chromatogram for the pyrolysis at $900{ }^{\circ} \mathrm{C}$ of quinic acid (shown in Figure 1) and of myo-inositol (shown in Figure 2).

\begin{tabular}{|c|c|c|c|c|c|c|}
\hline & Compound & $\begin{array}{l}\text { Retention time } \\
\quad(\min )\end{array}$ & MW & CAS\# & $\begin{array}{c}\text { Area \% } \\
\text { quinic acid }\end{array}$ & $\begin{array}{c}\text { Area \% } \\
\text { myo-inositol }\end{array}$ \\
\hline 1 & Carbon dioxide & 4.31 & 44 & $124-38-9$ & 14.15 & 15.73 \\
\hline 2 & Propene & 4.42 & 42 & $115-07-1$ & 0.83 & 4.74 \\
\hline 3 & Propyne & 4.79 & 40 & $74-99-7$ & 1.06 & 3.47 \\
\hline 4 & Formaldehyde & 4.79 & 30 & $50-00-0$ & - & 0.41 \\
\hline 5 & 1-Butene & 4.98 & 56 & $106-98-9$ & - & 0.83 \\
\hline 6 & 1-Butyne & 5.18 & 54 & $107-00-6$ & - & 2.13 \\
\hline 7 & 2-Methyl-1-propene & 5.05 & 56 & $115-11-7$ & 0.83 & - \\
\hline 8 & 1,3-Butadiene & 5.25 & 54 & $106-99-0$ & 1.29 & - \\
\hline 9 & 1-Buten-3-yne & 5.63 & 52 & $689-97-4$ & 0.20 & 0.50 \\
\hline 10 & Acetaldehyde & 5.82 & 44 & $75-07-0$ & 5.18 & 0.61 \\
\hline 11 & Furan & 7.54 & 68 & $110-00-9$ & - & 4.93 \\
\hline 12 & 1,3-Cyclopentadiene & 8.40 & 66 & $542-92-7$ & 2.68 & 3.73 \\
\hline 13 & 2-Propenal & 8.60 & 56 & $107-02-8$ & - & 0.98 \\
\hline 14 & Propanal & 8.66 & 58 & $123-38-6$ & 5.99 & - \\
\hline 15 & 2-Propanone (acetone) & 9.04 & 58 & $67-64-1$ & 4.07 & 0.51 \\
\hline 16 & 2-Butanone & 9.56 & 72 & $78-93-3$ & - & 0.70 \\
\hline 17 & 2-Methylfuran & 11.92 & 82 & $534-22-5$ & - & 0.17 \\
\hline 18 & 2-Methyl-2-propenal & 12.03 & 70 & $78-85-3$ & - & 0.55 \\
\hline 19 & 2-Propen-1-ol & 13.41 & 58 & $107-18-6$ & - & 0.37 \\
\hline 20 & Methyl vinyl ketone & 14.14 & 70 & $78-94-4$ & 0.48 & 1.13 \\
\hline 21 & 2,3-Butandione & 14.40 & 86 & $431-03-8$ & 1.23 & 0.52 \\
\hline 22 & Benzene & 16.29 & 78 & $71-43-2$ & 1.90 & 0.98 \\
\hline 23 & Hydroxyacetaldehyde & 17.73 & 60 & $141-46-8$ & 0.48 & 2.32 \\
\hline 24 & 2-Butenal & 19.33 & 70 & $123-73-9$ & 0.73 & 0.51 \\
\hline 25 & 2-Butenal (E) & 19.42 & 70 & $123-73-9$ & - & 0.42 \\
\hline 26 & Acetic acid & 19.96 & 60 & $64-19-7$ & - & 1.00 \\
\hline 27 & 3-Methyl-3-buten-2-one & 19.94 & 84 & $814-78-8$ & 0.84 & - \\
\hline 28 & 1-Penten-3-one & 20.33 & 84 & $1629-58-9$ & 0.48 & 1.05 \\
\hline 30 & Vinylfuran & 20.75 & 94 & $1487-18-9$ & 0.90 & - \\
\hline 31 & 1,4-Pentadien-3-ol & 21.45 & 84 & $922-65-6$ & 0.21 & - \\
\hline 32 & Ethyl-1-propenyl ether & 22.24 & 86 & $928-55-2$ & 0.09 & - \\
\hline 33 & 1-Hydroxy-2-propanone (acetol) & 22.45 & 74 & $116-09-6$ & 0.17 & 3.94 \\
\hline 34 & Toluene & 22.95 & 92 & $108-88-3$ & 0.36 & 0.55 \\
\hline 35 & Methyl formate & 23.78 & 60 & $107-31-3$ & - & 0.24 \\
\hline 36 & 2-Methylbutenal & 24.00 & 84 & $1115-11-3$ & 0.11 & - \\
\hline 37 & 3-Penten-2-one & 24.37 & 84 & $625-33-2$ & 0.82 & - \\
\hline 38 & Propanoic acid & 25.15 & 74 & $79-09-4$ & 0.09 & 0.28 \\
\hline 39 & 3-Methylfuran & 25.63 & 82 & $930-27-8$ & - & 0.11 \\
\hline
\end{tabular}

Note 1: Hydrogen, methane, ethylene, water were not analyzed due to the mass spectrometer settings $\mathrm{m} / \mathrm{z} \geq 28$. Note 2: Hydroxybenzenes (phenols) detected in the pyrolyzate are in bold. 
Table 1 (cont).

\begin{tabular}{|c|c|c|c|c|c|c|}
\hline & Compound & $\underset{(\mathrm{min})}{\text { Retention time }}$ & MW & CAS\# & $\begin{array}{l}\text { Area } \% \\
\text { quinic acid }\end{array}$ & $\begin{array}{c}\text { Area \% } \\
\text { myo-inositol }\end{array}$ \\
\hline 40 & Hexandione & 25.73 & 114 & $3848-24-6$ & 0.09 & - \\
\hline 41 & Propenoic acid & 26.10 & 72 & $79-10-7$ & - & 0.09 \\
\hline 42 & 2-Propenoic acid methyl ester & 26.65 & 86 & $96-33-3$ & 0.30 & - \\
\hline 43 & Cyclopentanone & 27.41 & 84 & $120-92-3$ & 0.16 & 0.32 \\
\hline 44 & 2-Methyl-2-butenal & 28.11 & 84 & $497-03-0$ & - & 0.74 \\
\hline 45 & $2(3 \mathrm{H})$-furanone & 28.30 & 84 & $20825-71-2$ & - & 0.15 \\
\hline 46 & $2(5 \mathrm{H})$-furanone & 28.87 & 84 & $497-23-4$ & - & 0.57 \\
\hline 47 & $\begin{array}{l}\text { 2-Oxopropionic acid methyl ester } \\
\text { (tentative) }\end{array}$ & 29.34 & 102 & $600-22-6$ & - & 0.27 \\
\hline 48 & Ethylbenzene & 27.74 & 106 & $100-41-4$ & 0.09 & - \\
\hline 49 & $\begin{array}{l}\text { 2-Butenoic acid ethenyl ester } \\
\text { (vinyl crotonate) }\end{array}$ & 28.60 & 112 & $14861-06-4$ & 0.16 & - \\
\hline 50 & 2-Methyl-2-propenoic acid & 29.48 & 86 & $79-41-4$ & 0.94 & - \\
\hline 51 & Butanedial & 29.68 & 86 & $638-37-9$ & 0.18 & 3.86 \\
\hline 52 & Styrene & 29.86 & 104 & $100-42-5$ & 0.15 & 0.46 \\
\hline 53 & 3-Butenoic acid & 30.14 & 86 & $625-38-7$ & 0.09 & - \\
\hline 54 & 1,2-Furancarboxaldehyde (furfural) & 30.39 & 96 & $98-01-1$ & - & 4.40 \\
\hline 55 & 2-Cyclopenten-1-one & 30.38 & 82 & $930-30-3$ & 0.47 & - \\
\hline 56 & 2-Propylfuran & 30.80 & 110 & $4229-91-8$ & - & 0.09 \\
\hline 57 & 3-Methyl-2-cyclopenten-1-one & 31.33 & 96 & $2758-18-1$ & 0.16 & - \\
\hline 58 & 2-Methyl-2-cyclopenten-1-one & 32.62 & 96 & $1120-73-6$ & 0.31 & 0.44 \\
\hline 59 & 3-Methyl-2-heptanone & 32.68 & 128 & 2371-19-9 & 0.63 & - \\
\hline 60 & 1-(2-Furanyl)ethanone & 33.15 & 110 & $1192-62-7$ & 0.05 & 0.16 \\
\hline 61 & Methacrylic anhydride & 33.60 & 154 & $760-93-0$ & 0.27 & - \\
\hline 62 & 2-Cyclopentene-1,4-dione & 33.59 & 96 & $930-60-9$ & - & 0.81 \\
\hline 63 & Glutaraldehyde & 34.24 & 100 & $111-30-8$ & - & 0.26 \\
\hline 64 & 2-Cyclohexen-1-one & 34.54 & 96 & $930-68-7$ & 0.32 & - \\
\hline 65 & 2-Hydroxy-2-cyclopenten-1-one & 34.59 & 98 & $10493-98-8$ & - & 5.50 \\
\hline 66 & $\begin{array}{l}\text { Dihydro-3-methylene-5-methyl- } \\
\text { 2- furanone }\end{array}$ & 34.71 & 112 & $62873-16-9$ & 0.30 & - \\
\hline 67 & $\begin{array}{l}\text { 2-Hydroxy-1-methylcyclopenten- } \\
\text { 3-one }\end{array}$ & 35.37 & 112 & $80-71-7$ & 0.08 & - \\
\hline 68 & 5-Methyl-2-furancarboxaldehyde & 35.61 & 110 & $620-02-0$ & 0.08 & - \\
\hline 69 & 2-Pentanal & 36.14 & 84 & $1576-87-0$ & 1.63 & - \\
\hline 70 & 1-Penten-3-one & 36.29 & 84 & $1629-58-9$ & 0.60 & - \\
\hline 71 & 3-Methyl-2-cyclopenten-2-one & 36.37 & 96 & $2758-18-1$ & - & 0.14 \\
\hline 72 & 1,2-Cyclohexanedione & 36.55 & 112 & $765-87-7$ & 1.01 & - \\
\hline 73 & $\begin{array}{l}\text { Dihydrofuran-2(3H)-one } \\
\text { (butyrolactone) }\end{array}$ & 36.57 & 86 & $96-48-0$ & - & 0.32 \\
\hline 74 & 2,4-Hexadienoic acid & 36.77 & 112 & $110-44-1$ & 0.11 & \\
\hline 75 & 2-Methyl-2-butenal (tentative) & 36.93 & 84 & $1115-11-3$ & - & 0.97 \\
\hline 76 & 2,3-Dihydrofuran (tentative) & 37.55 & 70 & $1191-99-7$ & 0.22 & - \\
\hline 77 & 2-Methyl-1,3-cyclopentanedione & 37.68 & 112 & $765-69-5$ & 0.34 & - \\
\hline 78 & 2H-Pyran-2-one (tentative) & 38.06 & 96 & $504-31-4$ & - & 0.12 \\
\hline 79 & 3-Methyl-1,2-cyclopentanedione & 38.11 & 112 & $765-70-8$ & 1.32 & - \\
\hline 80 & 3-Methyl-2(5H)-furanone & 38.39 & 98 & $22122-36-7$ & - & 0.12 \\
\hline
\end{tabular}


Table 1 (cont).

\begin{tabular}{|c|c|c|c|c|c|c|}
\hline & Compound & $\begin{array}{l}\text { Retention time } \\
\quad(\min )\end{array}$ & MW & CAS\# & $\begin{array}{l}\text { Area } \% \\
\text { quinic acid }\end{array}$ & $\begin{array}{c}\text { Area \% } \\
\text { myo-inositol }\end{array}$ \\
\hline 81 & 3-Methyl-2,5-furandione & 38.49 & 112 & $616-02-4$ & 2.00 & - \\
\hline 82 & Phenol & 38.75 & 94 & $108-95-2$ & 11.64 & 2.39 \\
\hline 83 & 2-Methylphenol & 40.29 & 108 & $95-48-7$ & 0.30 & - \\
\hline 84 & 4-Methylphenol & 41.20 & 108 & $106-44-5$ & 0.24 & 0.16 \\
\hline 85 & 3-Furancarboxylic acid methyl ester & 40.92 & 126 & $13129-23-2$ & - & 1.84 \\
\hline 86 & 3-Methylphenol & 41.43 & 108 & $108-39-4$ & 0.21 & 0.22 \\
\hline 87 & $\begin{array}{l}\text { 5,6-Dihydro-2H-pyran-2- } \\
\text { carboxaldehyde }\end{array}$ & 41.85 & 112 & $53897-26-0$ & 0.33 & - \\
\hline 88 & 1-Methylene-1H-indene & 42.19 & 128 & $2471-84-3$ & 0.11 & - \\
\hline 89 & 4-Methyl-5H-furan-2-one & 42.20 & 98 & $6124-79-4$ & - & 0.42 \\
\hline 90 & Dihydro-3-methyl-2,5-furandione & 42.43 & 114 & $4100-80-5$ & 0.30 & 0.15 \\
\hline 91 & 1,4-Cyclohexanedione & 42.82 & 112 & $637-88-7$ & 0.29 & - \\
\hline 92 & 2,5-Furandicarboxaldehyde & 43.36 & 124 & $823-82-5$ & - & 0.15 \\
\hline 93 & Benzoic acid & 44.30 & 122 & $65-85-0$ & 2.76 & - \\
\hline 94 & 3-Phenyl-2-propenal (tentative) & 44.93 & 132 & $104-55-2$ & - & 0.31 \\
\hline 95 & 4-Hydroxy-2-cyclohexen-1-one & 45.14 & 112 & $30182-12-8$ & 0.17 & - \\
\hline 96 & 5,5-Dimethyl-2(5H)-furanone & 45.51 & 112 & 20019-64-1 & 0.09 & - \\
\hline 97 & 3-Methyl-2,4(3H,5H)furandione & 45.66 & 114 & $1192-51-4$ & - & 0.24 \\
\hline 98 & 1,3-Dihydro-2H-inden-2-one & 46.73 & 132 & $615-13-4$ & - & 0.15 \\
\hline 99 & 2-Butenoic acid & 46.85 & 86 & $3724-65-0$ & 0.53 & - \\
\hline 100 & 1,2-Benzenediol diacetate & 47.10 & 194 & $635-67-6$ & 0.18 & - \\
\hline 101 & Biphenyl & 47.57 & 154 & $92-52-4$ & 0.15 & - \\
\hline 102 & 1,2-Benzenediol (catechol) & 47.92 & 110 & $120-80-9$ & 2.10 & 8.36 \\
\hline 103 & 1-(5-Methyl-2-furanyl)-1-propanone & 48.54 & 138 & $10599-69-6$ & 0.60 & - \\
\hline 104 & Unknown & 49.27 & 140 & $\mathrm{~N} / \mathrm{A}$ & 0.22 & - \\
\hline 105 & 1,4-Benzenediol (hydroquinone) & 50.75 & 110 & $123-31-9$ & 8.86 & 3.37 \\
\hline 106 & 1,3-Benzenediol (resorcinol) & 51.38 & 110 & $108-46-3$ & 0.61 & 1.68 \\
\hline 107 & 2-Methyl-1,4-benzenediol & 52.07 & 124 & $95-71-6$ & 0.55 & - \\
\hline 108 & $\begin{array}{l}\text { 4-Hydroxy-6,6-dimethylcyclo- } \\
\text { hexen-2-enone }\end{array}$ & 52.22 & 140 & N/A & 0.57 & - \\
\hline 109 & 1,1'-Biphenyl-2-ol & 52.90 & 170 & $90-43-7$ & 0.24 & - \\
\hline 110 & 4-Butoxyphenol & 54.16 & 166 & $122-94-1$ & 0.09 & - \\
\hline 111 & 1,2,3-Benzenetriol (pyrogallol) & 54.43 & 126 & $87-66-1$ & - & 1.42 \\
\hline 112 & 3-Phenylfuran & 55.60 & 144 & $13679-41-9$ & 0.10 & - \\
\hline 113 & 4-Hydroxybenzoic acid & 56.78 & 138 & $99-96-7$ & 0.28 & - \\
\hline 114 & 1,2,4-Benzenetriol & 58.36 & 126 & $533-73-3$ & - & 2.41 \\
\hline 115 & 1,3,5-Benzenetriol & 58.60 & 126 & $108-73-6$ & - & 0.38 \\
\hline 116 & $\begin{array}{l}\text { 3-Hydroxy-2-methyl-4H-pyran-4-one } \\
\text { (maltol) }\end{array}$ & 59.89 & 126 & $118-71-8$ & - & 0.26 \\
\hline 117 & $1,2,3,5$-Cyclohexantetraol isomer & 61.64 & 148 & N/A & 2.67 & - \\
\hline 118 & 1,2,3,5-Cyclohexantetraol & 62.19 & 148 & $53585-08-3$ & 8.06 & - \\
\hline 119 & 1,2,3,5-Cyclohexantetraol isomer & 62.58 & 148 & $\mathrm{~N} / \mathrm{A}$ & 0.30 & - \\
\hline 120 & $1,2,3,5$-Cyclohexantetraol isomer & 63.46 & 148 & $\mathrm{~N} / \mathrm{A}$ & 0.22 & - \\
\hline 121 & Myo-inositol & 63.93 & 180 & 87-89-8 & - & 2.86 \\
\hline
\end{tabular}


Corresponding author:

Serban C. Moldoveanu

R. J. Reynolds Tobacco Co.

Winston-Salem, NC 27105

USA

moldovs@rjrt.com 